\title{
Effects of Ruminally Protected Amino Acid-enriched Fatty Acids on Growth Performance and Carcass Characteristics of Fattening Hanwoo Cows
}

\author{
Byung Ki Park ${ }^{1}$, Sang Min Lee ${ }^{1}$, Hyeong Cheol Kim${ }^{1}$, Sun Sik Chang ${ }^{1}$, Tae Il Kim ${ }^{1}$ Young Moo Cho ${ }^{1}$, \\ Chang Weon $\mathrm{Choi}^{2}$, Seong Koo Hong ${ }^{1}$ and Eung Gi Kwon ${ }^{1} *$ \\ ${ }^{1}$ National Institute of Animal Science, RDA, Korea, ${ }^{2}$ Department of Animal Resources, Daegu University, Korea
}

\begin{abstract}
This study was conducted to determine the effects of ruminally protected amino acid-enriched fatty acids (RPAAFA) on body weight gain, feed intake and carcass characteristics of fattening Hanwoo cows. Twenty eight Hanwoo cows, 6.0 \pm 1.7 years old and weighing an average of $463.2 \pm 77.6 \mathrm{~kg}$, were used for 4 months. Animals were fed a basal diet supplemented with RPAAFA at 0 $\mathrm{g}$ (control) and $100 \mathrm{~g}$ (treatment), respectively. Average daily gain, dry matter intake and feed conversion ratio were not different among the control and treatment. The supplementation of RPAAFA did not affect carcass weight and rib eye areas. Quality grade score $\left(1^{++}, 1^{+}\right.$and 1$)$ for treatment was higher in RPAAFA supplemented group compared with the control, whereas no differences appeared in meat color, fat color, texture and maturity. Thus present results indicate that supplementation of RPAAFA may be recommended for producing high quality beef from fattening Hanwoo cows.
\end{abstract}

(Key words : Hanwoo cows, Ruminally protected amino acid-enriched fatty acids, Carcass characteristics, Beef fattening)

\section{INTRODUCTION}

In recent years, slaughter percentage of Hanwoo cows was $46.6 \%$, and the appearance of high quality grade $\left(1^{++}, 1^{+}\right.$and 1) was 56.3\% (APGS, 2009). Several Hanwoo cows have been culled by farmers each year owing to several reasons, such as reproductive disorders, genetic problems, etc. Cows have experience of pregnancy, parturition and nursing for a long time. In general, fattening period of Hanwoo cows varies from 4 to 10 months in Korea. It is difficult for farmers to keep their cows for approximately 10 months due to increasing feed expenses in recent times. Thus, fattening period of cows is desirable to shorten as far as possible. Instead, it is suggested that energy- and protein (amino acid)-rich feed resources are used for beef cattle because productivity can be improved substantially by strategic supplementation with energy and amino acid.

When Ca salts of fatty acids from vegetable oils were included in beef cattle diets for additional energy supply, there were relatively few effects on rumen fermentation (Schauff and Clark, 1989). In addition, inclusion of protected fatty acids in ruminant diets improves energy efficiency due to the lower ruminal production of methane and direct use of long-chain fatty acids in the metabolic pathways of fat synthesis, replacing the need for acetate and glucose (Doreau and Chilliard, 1997; Machmüller et al., 2000).

Productive diets for beef cattle have been used with various sources of undegradable protein, because production of microbial protein (amino acids) alone is insufficient to supply adequate amounts of amino acids for optimal production (Kung and Rode, 1996). However, most protein feeds are a poor source of at least one essential amino acid (Merchen and Titgemeyer, 1992), and methionine and lysine are generally the first limiting amino acids for production of beef cattle (Hussein and Berger, 1995). Supplementation of ruminally protected methionine and lysine improved body weight gain or feed efficiency of growing steers (Wright and Loerch, 1988).

Thus, the objective of the present study was to determine the effects of simultaneous supply of fatty acids and limiting amino acids (methionine and lysine) on growth performance and carcass characteristics of Hanwoo cows with a minimal fattening period (4 months).

* Corresponding author: Eung Gi Kwon, Hanwoo Experiment Station, National Institute of Animal Science, RDA, Korea. Tel: 82-33-330-0612, Fax: 82-33-330-0660, E-mail: kug2237@korea.kr 


\section{MATERIALS AND METHODS}

1. Animals, experimental design, feeding and management

Twenty eight Hanwoo cows of $6.0 \pm 1.7$ years old (parity: $2.1 \pm 0.9)$ and an average body weight of $463.2 \pm 77.6 \mathrm{~kg}$, were divided into 2 groups for 4 months. Marbling score were predicted between the $13^{\text {th }}$ thoracic and $1^{\text {st }}$ lumbar vertebrae of cows using ultra-sound scanning equipment (Aquila, 3.5 $\mathrm{MHz}, 18 \mathrm{~cm}$ linear probe, Pie Medical, Netherlands) at the start of the experiment. Animals were fed a basal diet supplemented with ruminally protected amino acid-enriched fatty acids (RPAAFA) at $0 \mathrm{~g}$ (control) and $100 \mathrm{~g}$ (treatment), respectively.

The treatment and control were arranged in 4 pens with 7 cows per pen $(5.3 \times 10.6 \mathrm{~m})$ which had a concreted floors with sawdust bedding. Animals were offered commercial concentrate ad libitum, and rice straw at $4.0 \mathrm{~kg} / \mathrm{animal} / \mathrm{d}$. The ingredients and chemical compositions of the experimental diets are presented in Table 1. Rice straw was supplied at 08:00 h daily, and the concentrates offered twice daily in two equal portions at 08:00 and 16:00 h. Cows had free access to fresh water and mineral block during the whole experimental period. RPAAFA and melengesterol acetate (MGA) were fed as a top dressing at the morning feeding. MGA was fed at $0.5 \mathrm{mg} / \mathrm{animal} / \mathrm{d}$ to suppress the estrous cycle during the experimental period. RPAAFA was provided by Nuvo Bio \& Technologies Co. (Seoul, Korea). Chemical compositions of RPAAFA are presented in Table 2. MGA was purchased from Dong Bang Co. (Seoul, Korea).

\section{Sampling, measurements and analyses}

The diets used in this study were dried by forced-air oven (at $60^{\circ} \mathrm{C}, 48 \mathrm{~h}$ ), ground by a Wiley mill (Thomas scientific, Model 4, USA) and analyzed for moisture, crude protein, ether extract, crude fiber and crude ash according to the procedures of the AOAC (1990). The concentration of neutral detergent fiber (NDF) corrected for residual ash was determined with heat-stable amylase and sodium sulphate according to the method of Van Soest et al. (1991), while the content of acid detergent fiber(ADF) corrected for residual ash was determined according to the procedure of the AOAC (1990)

Cows were weighed before the morning feeding (at 08:00
Table 1. Ingredients and chemical compositions of the experimental diet

\begin{tabular}{lcc}
\hline Item & Concentrate & Rice straw \\
\hline \hline Ingredient (\%) & & \\
Corn grain & 24.38 & - \\
Wheat grain & 16.00 & - \\
Barley grain & 1.70 & - \\
Molasses & 5.00 & - \\
Tapioca & 7.73 & - \\
Wheat flour and bran & 9.05 & - \\
Corn gluten feed & 15.65 & - \\
Soybean meal & 11.35 & - \\
Lupin & 6.00 & - \\
Ultra fat and tallow & 0.60 & - \\
Trace materials & 2.54 & - \\
Chemical composition, analyzed (\%) & & \\
Dry matter & $90.52 \pm 0.12$ & $91.43 \pm 0.08$ \\
Crude protein & $14.08 \pm 0.23$ & $4.39 \pm 0.14$ \\
Ether extract & $4.80 \pm 0.02$ & $2.36 \pm 0.01$ \\
Crude ash & $9.41 \pm 0.05$ & $13.07 \pm 0.12$ \\
Crude fiber & $5.54 \pm 0.56$ & $29.57 \pm 0.09$ \\
Neutral detergent fiber & $28.05 \pm 0.68$ & $70.21 \pm 0.96$ \\
Acid detergent fiber & $11.10 \pm 0.17$ & $38.13 \pm 0.40$ \\
\hline
\end{tabular}

Means \pm standard deviation.

Table 2. Chemical composition of ruminally protected amino acid-enriched fatty acids (RPAAFA)

\begin{tabular}{lc}
\hline \multicolumn{1}{c}{ Item } & RPAAFA \\
\hline \hline Dry matter (\%) & 99.05 \\
Ether extract (\%) & 51.17 \\
Fatty acids (\%) & \\
$\quad$ Saturated fatty acids & 16.07 \\
Mono-unsaturated fatty acids & 43.29 \\
$\quad$ Poly-unsaturated fatty acids & 40.63 \\
Amino acids (\%) & \\
$\quad$ Methionine & 9.09 \\
Lysine & 19.83 \\
\hline
\end{tabular}

h) every month during the experimental period. Dietary refusals were collected and weighed every day. Feed conversion ratio was expressed as average dry matter intake per average daily gain (ADG).

Back fat thickness and marbling score were predicted 
between the $13^{\text {th }}$ thoracic and $1^{\text {st }}$ lumbar vertebrae of cows using ultra-sound scanning equipment (Aquila, 3.5 MHz, 18 cm linear probe, Pie Medical, Netherlands) at every month during the experimental period.

Carcass characteristics such as yield and quality grades were assessed at $24 \mathrm{~h}$ post-mortem by an experienced carcass grader of the Animal Products Grading Service (APGS, 2009), Korea. Quality (marbling score, meat color, fat color, texture and maturity) and yield (cold carcass weight, back fat thickness and rib eye area) characteristics were recorded. After a 24-h chill, cold carcass weights were measured and then the left side of each carcass was cut between the last rib and the first lumbar vertebrae to determine quality grade.

The quality grade was determined by assessing the degree of marbling and firmness in the cut surface of the rib eye, in relation to the maturity, meat color and fat color of the carcass. The rib eye area was measured from longissimus muscle taken at the $13^{\text {th }}$ rib and back fat thickness was also measured at the $13^{\text {th }}$ rib. Yield index was calculated as follows: Yield index: $68.184-(0.625 \times$ back fat thickness $(\mathrm{mm}))+\left(0.130 \times\right.$ rib eye area $\left.\left(\mathrm{cm}^{2}\right)\right)-(0.024 \times$ dressed weight amount $(\mathrm{kg}))+3.23$.

The degree of marbling was evaluated with the Korean Beef Marbling Standard, and the scores of meat color and fat color were made using the color standard (APGS, 2009). The scores for texture and maturity were made using the APGS reference index(APGS, 2009). The grading ranges were 1 to 9 for marbling score with higher numbers for better quality $(1=$ devoid, 9 = abundant); meat color $(1=$ bright red, 7 = dark red); fat color ( $1=$ creamy white, $7=$ yellowish); texture ( 1 = soft, 3 = firm); maturity ( 1 = young, 9 = old).

\section{Statistical analyses}

Comparisons of growth performance and carcass characteristics of Hanwoo cows were analyzed by t-test using the SAS software package (1999) to compare the significant difference between the two groups $(\mathrm{p}<0.05)$.

\section{RESULTS AND DISCUSSION}

\section{Growth performance}

Average daily gain (ADG) was not significantly different between the two groups (Table 3). Dry matter intake (DMI) was not affected by supplementation of RPAAFA. Feed
Table 3. Effects of ruminally protected amino acidenriched fatty acids on growth performance of Hanwoo cows

\begin{tabular}{lrrc}
\hline \multicolumn{1}{c}{ Item } & \multicolumn{1}{c}{ Control } & Treatment & $\operatorname{Pr}>|\mathrm{t}|$ \\
\hline \hline Initial body weight $(\mathrm{kg})$ & $459.5 \pm 81.8$ & $466.9 \pm 73.0$ & 0.81 \\
Final body weight $(\mathrm{kg})$ & $629.9 \pm 81.5$ & $638.8 \pm 68.8$ & 0.77 \\
Average daily gain $(\mathrm{kg})$ & $1.10 \pm 0.19$ & $1.11 \pm 0.18$ & 0.89 \\
Feed intake $(\mathrm{kg} / \mathrm{d})$ & & & \\
$\quad$ Concentrate & $11.85 \pm 0.27$ & $11.77 \pm 0.54$ & 0.71 \\
Rice straw & $1.99 \pm 0.01$ & $2.00 \pm 0.01$ & 0.62 \\
$\quad$ Dry matter intake & $12.55 \pm 0.24$ & $12.47 \pm 0.50$ & 0.72 \\
Feed conversion ratio & $11.77 \pm 2.10$ & $11.56 \pm 1.96$ & 0.80 \\
\hline
\end{tabular}

Means \pm standard deviation.

conversion ratio was similar between control and treatment.

The present results were supported by previous studies, such as those of Ngidi et al. (1990) who reported that ADG, DMI and feed conversion ratio of Angus-Hereford crossbred steers fed high concentrate diets were not affected by supplementing with $2 \%$ Ca salts of fatty acids and Gilbert et al. (2003) who found no differences in ADG, DMI and feed conversion ratio of Brangus steers by supplementing with protected canola lipid.

Strasia et al. (1986) detected no response in growth performance when growing steers were supplemented with as much as $20 \mathrm{~g} / \mathrm{d}$ of ruminally protected methionine. Some improvements in gain or feed efficiency were detected when ruminally protected lysine and methionine (RPLM) was supplemented (Wright and Loerch, 1988; Veira et al., 1991), but these results demonstrated neither consistent responses to graded levels of supplementation nor large improvements in growth performance. Previous researches also suggested that source of supplemental CP (Merchen and Titgemeyer, 1992) or CP contents of concentrate (Deetz et al., 1985) can influence growth response of growing or fattening cattle to RPLM supplementation. In addition, most previous trials evaluated supplementation of RPLM for the growing steers, but the present study was conducted to provide such evaluation for older cows which have little gain related to accumulation of protein (amino acids) in the tissues. Therefore, RPAAFA had no positive effects on ADG, DMI and feed conversion ratio of Hanwoo cows in the present study.

Jeong et al. (2006) reported $0.57 \mathrm{~kg}$ of ADG of cows during 8 months of fattening period, and the ADG was 
lower compared with ADG of present study. The result showed that increased ADG was related to lower age, parity and fattening period of cows than previous study which used older cows (age: $8.5 \pm 2.5$, parity: $6.5 \pm 1.7$ ). The ADG in the present study was higher in comparison with earlier study by Kook and Kim (2003) who reported that ADG of Hanwoo cows (parity: 2 to 3 ) were $0.18 \mathrm{~kg}$ during 4 months of fattening period.

\section{Ultra-sound measurements and carcass chara- cteristics}

Back fat thickness and marbling scores did not differ between the two groups (Table 4), although increase of marbling score tended to be higher for treatment (3.21 to 4.14) compared with the control (3.50 to 4.00) from 3 to 4 months. Similar to the present results, Salinas et al. (2006) reported that back fat thickness and rib eye area measured by ultra-sound scanning were not affected by supplementing with Ca salts of tallow.

In carcass yield traits, rib eye area, back fat thickness, yield index were similar between the two groups (Table 5). In the yield grades of control, incidence of $\mathrm{A}, \mathrm{B}$ and $\mathrm{C}$ grades resulted in 21, 64 and 14\%, respectively, whereas, treatment resulted in 29, 64 and 7\%, respectively. In carcass quality traits, meat color, fat color, texture and maturity were

Table 4. Effects of ruminally protected amino acidenriched fatty acids on back fat thickness and marbling score measured by ultra-sound scanning of Hanwoo steers at monthly intervals

\begin{tabular}{lcccc}
\hline Item & Months & Control & Treatment & $\operatorname{Pr}>|\mathrm{t}|$ \\
\hline \hline Back fat thickness (mm) & 0 & $4.36 \pm 3.49$ & $3.71 \pm 2.20$ & 0.58 \\
& 1 & $7.54 \pm 5.20$ & $6.31 \pm 3.75$ & 0.50 \\
& 2 & $8.46 \pm 4.82$ & $7.93 \pm 3.03$ & 0.74 \\
& 3 & $9.79 \pm 6.05$ & $8.00 \pm 3.58$ & 0.37 \\
& 4 & $10.57 \pm 6.7010 .21 \pm 5.01$ & 0.88 \\
\hline Marbling score & 0 & $1.93 \pm 0.70$ & $1.93 \pm 1.10$ & 1.00 \\
& 1 & $2.46 \pm 1.39$ & $2.71 \pm 1.98$ & 0.72 \\
& 2 & $3.14 \pm 1.64$ & $2.93 \pm 1.67$ & 0.74 \\
& 3 & $3.50 \pm 1.64$ & $3.21 \pm 1.90$ & 0.68 \\
4 & $4.00 \pm 1.51$ & $4.14 \pm 1.77$ & 0.83 \\
\hline
\end{tabular}

Means \pm standard deviation.
Table 5. Effects of ruminally protected amino acidenriched fatty acids on carcass characteristics of Hanwoo cows

\begin{tabular}{lccc}
\hline \multicolumn{1}{c}{ Item } & Control & Treatment & $\operatorname{Pr}>|\mathrm{t}|$ \\
\hline \hline Yield traits ${ }^{1)}$ & & & \\
Carcass weight $(\mathrm{kg})$ & $359.3 \pm 58.3$ & $366.4 \pm 47.6$ & 0.74 \\
Rib eye area $\left(\mathrm{cm}^{2}\right)$ & $85.07 \pm 6.52$ & $89.57 \pm 10.79$ & 0.21 \\
Back fat thickness (mm) & $12.29 \pm 5.66$ & $11.00 \pm 5.06$ & 0.55 \\
Yield index & $66.17 \pm 4.49$ & $67.39 \pm 3.47$ & 0.45 \\
Yield grade (A:B:C, head) & $21: 64: 14$ & $29: 64: 7$ & - \\
Quality traits ${ }^{2)}$ & & & \\
Marbling score & $3.79 \pm 1.86$ & $4.29 \pm 1.71$ & 0.48 \\
Meat color & $4.93 \pm 0.59$ & $5.29 \pm 0.70$ & 0.17 \\
Fat color & $3.43 \pm 0.62$ & $3.86 \pm 0.52$ & 0.07 \\
Texture & $1.79 \pm 0.41$ & $1.57 \pm 0.49$ & 0.24 \\
Maturity & $6.36 \pm 1.99$ & $6.43 \pm 1.18$ & 0.91 \\
Quality grade & & & \\
$\quad\left(1^{++}: 1^{+}: 1: 2: 3\right.$, head) & $0: 21: 14: 43: 21$ & $0: 29: 29: 29: 14$ & - \\
Auction price (won/kg) & $11,565 \pm 2,683$ & $11,867 \pm 1,974$ & 0.75 \\
\hline
\end{tabular}

Means \pm standard deviation.

1) Area was measured from longissmus muscle taken as $13^{\text {th }}$ rib and back fat thickness were also measured at $13^{\text {th }}$ rib; Yield index was calculated using the following equation: 68.184$(0.625 \times$ back fat thickness $(\mathrm{mm}))+\left(0.130 \times\right.$ rib eye area $\left.\left(\mathrm{cm}^{2}\right)\right)-$ $(0.024 \times$ dressed weight amount $(\mathrm{kg}))$; yield grades were classified as A (high yield), B and C (low yield).

${ }^{2)}$ Grading ranges are 1 to 9 for marbling score with higher numbers for better quality $(1=$ devoid, $9=$ abundant); meat color $(1=$ bright red, 7 = dark red); fat color $(1=$ creamy white, $7=$ yellowish); texture (1 = soft, 3 = firm); maturity ( 1 = young, $9=$ old); quality grades were classified as $1^{++}$(very high quality), $1^{+}$, 1, 2 and 3 (low quality).

similar between the two groups. The quality grade scores $\left(1^{++}, 1^{+}\right.$and 1$)$ was 35 and $58 \%$ in control and treatment, respectively.

In the present study, marbling score and high quality grade was increased by supplementation of RPAAFA in treatment group. It was thought that inclusion of protected fatty acids in ruminant diets improves energy efficiency due to the lower ruminal production of methane and direct use of long-chain fatty acids in the metabolic pathways of fat synthesis, precluding the need for acetate and glucose (Doreau and Chilliard, 1997; Machmüller et al., 2000). In addition, methionine of RPAAFA can be associated with increase in marbling score and high quality grade. This response is most likely related to the role of methionine as 
a methyl donor in transmethylation reactions occurring during lipid biosynthesis (Lehninger, 1977; Mayes, 1981). Moreover, Park et al. (2010) reported that supplementation with $100 \mathrm{~g}$ of amino acid-enriched ruminally protected fatty acids had positive effects on marbling score and meat quality grade due to increasing supply of fatty acids and limiting amino acids (methionine and lysine) in finishing Hanwoo steers.

The appearance rate of desirable high quality grade in the present study was higher (supplemented with RPAAFA) and lower (control) in comparison with earlier studies by Jeong et al. (2006) and Kook and Kim (2003) who reported that the appearance rates were 30 and $67 \%$, respectively. The result showed that the appearance rates of high quality grade were related to maturity score which were 6.40 (present study), 8.13 (Jeong et al.) and 2.22 (Kook and Kim), respectively, although marbling score was similar among three studies (4.04 vs. 3.98 vs. 3.78).

Thus, the present results indicated that supplementation of RPAAFA had positive effects on the quality grades due to increasing supply of fatty acids and limiting amino acids (methionine and lysine), although RPAAFA had no effects on growth performance and carcass characteristics in Hanwoo cows. However, the appearance rate of high quality grades $\left(1^{++}, 1^{+}\right.$and 1$)$ was $58 \%$ in treatment which was similar to $56 \%$ of the whole country in 2009. Therefore, more research will be needed to determine the effects of extended fattening period to increase production of high quality beef in fattening Hanwoo cows.

\section{REFERENCES}

AOAC. 1990. Official Methods of Analysis, Association of Official Analytical Chemists, Washington, DC.

APGS. 2009. Grade Rule for Cattle Carcass in Korea. Available: http://www.ekape.or.kr/gradeinfo/statistics/.

Deetz, L. E., Papas, A. M. and Benton, C. H. 1985. Performance of finishing steers fed rumen-protected methionine and/or lysine. J. Anim. Sci. 61 (Suppl. 1):486 (Abstr.).

Doreau, M. and Chilliard, Y. 1997. Digestion and metabolism of dietary fat in farm animals. Br. J. Nutr. 78:15-35.

Gilbert, C. D., Lunt, D. K., Miller, R. K. and Smith, S. B. 2003. Carcass, sensory, and adipose tissue traits of Brangus steers fed casein-formaldehyde-protected starch and/or canola lipid. J. Anim. Sci. 81:2457-2468.

Hussein, H. S. and Berger, L. L. 1995. Feedlot performance and carcass characteristics of Holstein steers as affected by source of dietary protein and level of ruminally protected lysine and methionine. J. Anim. Sci. 73:3503-3509.

Jeong, J., Lee, S. S., Park, N. H., Sung, N. I., Jang, Y. H., Choi, S. H., Song, M. K., Suh, H. K. and Lee, M. I. 2006. Effects of melengesterol acetate, selenium and vitamin E supplemental feeding on growth, carcass and longissimus dorsi muscle traits in Hanwoo cull cows. Kor. J. Anim. Sci. Technol. 48:255-268.

Kook, K. and Kim, K. H. 2003. The effects of supplemental levels of bamboo vinegar on growth performance, serum profile and meat quality in fattening Hanwoo cow. Kor. J. Anim. Sci. Technol. 45:57-68.

Kung, L. and Rode, L. M. 1996. Amino acid metabolism in ruminants. Anim. Feed Sci. Technol. 59:167-172.

Lehninger, A. L. 1977. Biochemistry. $2^{\text {nd }}$ ed. Worth Publ., Inc., New York, NY.

Machmüller, A., Ossowski, D. A. and Kreuzer, M. 2000. Comparative evaluation of the effects of coconut oil, oilseeds and crystalline fat on methane release, digestion and energy balance in lambs. Anim. Feed Sci. Technol. 85:41-60.

Mayes, P. A. 1981. Metabolism of lipids: II. Role of the tissue. In: Harper's Review of Biochemistry (18 ${ }^{\text {th }}$ Ed.) (Ed. D. W. Martin, P. A. Mayes and V. W. Rodwell). pp 222-244. Lange Med. Publ., Los Altos, CA.

Merchen, N. R. and Titgemeyer, E. C. 1992. Manipulation of amino acid supply to the growing ruminant. J. Anim. Sci. 70:3238-3247.

Ngidi, M. E., Loerch, S. C., Fluharty, F. L. and Palmquist, D. L. 1990. Effects of calcium soaps of long-chain fatty acids on feedlot performance, carcass characteristics and ruminal metabolism of steers. J. Anim. Sci. 68:2555-2565.

Park, B. K., Choi, N. J., Kim, H. C., Kim, T. I., Cho, Y. M., Oh, Y. K., Im, S. K., Kim, Y. J., Chang, J. S., Hwang, I. H., Jang, H. Y., Kim, J. B. and Kwon, E. G. 2010. Effects of amino acid-enriched ruminally protected fatty acids on plasma metabolites, growth performance and carcass characteristics of Hanwoo steers. Asian-Aust. J. Anim. Sci. 23:1013-1021.

Salinas, J., R. Ramírez, G., Domínguez, M. M., Reyes-Bernal, N., Trinidad-Lárraga, N. and Montaño, M. F. 2006. Effect of calcium soaps of tallow on growth performance and carcass characteristics of Pelibuey lambs. Small Rumin. Res. 66:135139.

SAS. 1999. SAS/STAT Software for PC. Release 6.11, SAS Institute, Cary, NC, U.S.A

Schauff, D. J. and Clark, J. H. 1989. Effects of prilled fatty acids and calcium salts of fatty acids on rumen fermentation, nutrient digestibilities, milk production and milk composition. 
J. Dairy Sci. 72:917-927.

Strasia, C. A., Martin, J. J., Gill, D. R. and Owens, F. N. 1986 Ruminal escape methionine and lysine for finishing steers. J. Anim. Sci. 63 (Suppl. 1):406 (Abstr.).

Van Soest, P. J., Robertson, J. B. and Lewis, B. A. 1991. Methods of dietary fiber, neutral detergent fiber and non-starch polysaccharides in relation to animal nutrition. J. Dairy Sci. 74:3583-3597.
Veira, D. M., Seone, J. R. and Prolux, J. G. 1991. Utilization of grass silage by growing cattle: effect of a supplement containing ruminally protected amino acids. J. Anim. Sci. 69: 4703-4709.

Wright, M. D. and Loerch, S. C. 1988. Effects of rumen protected amino acids on ruminant nitrogen balance, plasma amino acid concentrations and performance. J. Anim. Sci. 66:2014-2027.

(Received Jul. 16, 2010; Revised Nov. 22, 2010; Accepted Nov. 23, 2010) 